\title{
Optimal Control Dynamic Relationships and Fiscal Policies in Indonesia's Economy
}

\author{
Submitted 14/12/20, $1^{\text {st }}$ revision 21/01/21, $2^{\text {nd }}$ revision 15/02/21, accepted 20/03/21 \\ Intan Syahrini ${ }^{1}$, Yusri Hazmi ${ }^{2}$, Raja Masbar ${ }^{3}$, Aliasuddin $^{4}$, Said Munzir $^{5}$
}

\begin{abstract}
:
Purpose: This study aims to estimate optimal control in the Keynesian macroeconomic model for the Indonesian economy.

Approach/Methodology/Design: Researchers use optimal control in retrieval in connection with macro-econometric models' problems. One way is used to influence macroeconomic variables, which include national income and expenditure. In this study, optimal control is used on the expenditure side, namely, to influence changes in the budget deficit. The data used is secondary data in the form of time series, in the period 1990-2018. Simulation is used to obtain the optimal value, with a simulation period starting from 2019-2023 - optimal control theory through fiscal policy on the budget deficit.

Findings: The results showed that the optimal value of macroeconomic variables has a deviation from the target value for all macroeconomic variables, consumption, investment, exports, imports, GDP, and budget deficits. So, it can be seen that optimal growth, through macroeconomic variables that influence it, including GDP, consumption, investment, exports, and imports with the budget deficit as a control variable. In the scientific concept, optimal control theory is used as a tool to determine an optimal policy.

Practical Implication: The research provides a solution to the budget deficit problem. The government needs to control the deficit so that optimal economic growth will be obtained. The largest deviation from the average during the simulation period occurred in GDP, followed by investment, exports, and fiscal policy deficits. Meanwhile, the lowest average deviation is found in imports.
\end{abstract}

Original/Value: This research contributes and provides solutions to fiscal Policy. They are mostly related to the budget deficit.

Keywords: Optimal control, consumption, investment, export, import, budget deficit.

JEL Classification Code: E6, E62, F3.

Research Type: Research Paper.

${ }^{1}$ Ph.D. Scholar in Economics, Faculty of Economics and Business, Syiah Kuala University, IndonesiaIntansyahrini@unsyiah.ac.id

${ }^{2}$ Lecturer, Department of Commerce, Lhokseumawe State Polytechnic, Indonesia. yusri.poltek@gmail.com

${ }^{3}$ Professor, Faculty of Economics and Business, Syiah Kuala University, Indonesia. raja.masbar@unsyiah.ac.id

${ }^{4}$ Senior Lecturer, Faculty of Economics and Business, Syiah Kuala University, Indonesia. aliasuddin@unsyiah.ac.id

${ }_{5}^{5}$ Senior Lecturer, Faculty of Economics and Business, Syiah Kuala University, Indonesia. smunzir@unsyiah.ac.id 


\section{Introduction}

Several studies have stated that the budget deficit positively affects economic growth (Gupta et al., 2005; Nguyen, 2015). Research by Saleh (2004) and Bose et al. (2007) on the budget deficit's effect on macroeconomic variables. The budget deficit financing affects economic growth due to the government increasing spending, which encourages increased investment. This results in economic growth, which occurs through the absorption of labor (Saleh, 2004). Bose et al. (2007) conducted a study using panel data on 30 developing countries. The research states that the budget deficit has a positive effect on economic growth in developing countries. Abimayu (2005) states that the government budget deficit is an expansionary fiscal stimulus. Expansive fiscal policy is intended to encourage economic growth.

However, several studies have found that the budget deficit tends to hurt the economy. Research conducted by Algifari (2009) states that the budget deficit hurts economic growth. In conditions of economic crisis, the government tends to increase spending. Ezeabasili (2012) states that the budget deficit positively affects the economy in the short term. However, in the long run, it will have a negative effect. The budget deficit resulted in the domestic economy becoming vulnerable to the global economy. A budget deficit tends to hurt the economy. Research conducted by Algifari (2009) states that the budget deficit hurts economic growth. In conditions of economic crisis, the government tends to increase spending. Ezeabasili (2012) states that the budget deficit positively affects the economy in the short term. However, in the long term, it will have a negative effect. The budget deficit resulted in the domestic economy becoming vulnerable to the global economy.

A budget deficit tends to hurt the economy. Research conducted by Algifari (2009) states that the budget deficit hurts economic growth. In conditions of economic crisis, the government tends to increase spending. Ezeabasili (2012) states that the budget deficit positively affects the economy in the short term. However, in the long term, it will have a negative effect. The budget deficit resulted in the domestic economy becoming vulnerable to the global economy. In the short term, the budget deficit has a positive effect on the economy. However, in the long term, it will have a negative effect. The budget deficit resulted in the domestic economy becoming vulnerable to the global economy. In the short term, the budget deficit has a positive effect on the economy. However, in the long term, it will have a negative effect. The budget deficit resulted in the domestic economy becoming vulnerable to the global economy.

Before the global financial crisis, the Indonesian economy grew at an average of 6.04 percent per year (2000-2007). During the global crisis (2008 and 2009), it grew by around 5.3 percent. During 2010-2017, a period of economic recovery, the average economic growth was 5.57 percent per year. The slowdown in economic growth resulted from high household consumption, which reached 57.3 percent of GDP. Investment contributed 31.9 percent in 2013 and 32.2 percent in 2017. At the same time, net exports began to be positive since 2015 and contributed 1.2 percent to GDP. This is in line with the increasing export performance. It is hoped that household 
consumption's role as the primary support for economic growth can be shifted through investment. Investment can affect production capacity and competitiveness. So that it will encourage economic growth, create jobs, and increase income. This requires the role of the government, primarily through fiscal policy. According to BuneaBontas et al. (2008), fiscal policy as a financial instrument is used to manipulate revenues and expenditures.

Fiscal policy aims to allocate resources, stabilize the economy, and distribute income. Government spending and tax revenue as the primary fiscal policy tool Fiscal policy aim to allocate resources, stabilize the economy, and distribute income. Government spending and tax revenue as the primary fiscal policy tool Fiscal policy aim to allocate resources, stabilize the economy and distribute income - government spending and tax revenue as the primary fiscal policy tool (Tanzi, 2008). Fiscal policy through a budget deficit is aimed at stimulating the economy through the supply and demand side. On the demand side, the increase in income originates from an increase in private consumption, investment, government spending, an increase in exports, and a decrease in imports. Keynes's understanding states that fiscal policy through an increase in government spending is intended to boost demand. Through fiscal policy, aggregate demand increases and occurs when the components of the goods market or real sector increase.

Moreover, this can be done through fiscal stimulus. The government can control fiscal policy in fluctuating economic conditions, namely through the budget deficit policy. However, fiscal policy is less effective without being supported by appropriate and consistent monetary policy. Moreover, it hinders the pace of the economy. Fiscal stimulus should be able to increase aggregate demand. However, it can lead to unproductive results without being balanced with the monetary policy (Abimayu, 2003).

Optimal state income is an essential key in sound, sustainable fiscal management and the primary source of funding in realizing the state's goals, particularly creating people's welfare and stable economic growth and increasing state income, as evidence of national independence reducing dependence on financing originating from debt. To achieve a stable economy, fiscal policy control is needed, mostly related to the budget deficit. Moreover, this can be done using optimal control theory. In the field of economics, researchers determine optimal policies to answer problems in the macroeconomic model. One strategy is used to influence economic variables, such as national income, to achieve the government's optimal value.

\section{Literature Review}

\subsection{Fiscal Policy}

According to Bunea-Bontas et al. (2008), fiscal policy as a financial instrument is used to manipulate revenues and expenditures. Fiscal policy aims to allocate resources, stabilize the economy, and distribute income. Government spending and 
tax revenue as the primary fiscal policy tool Fiscal policy aim to allocate resources, stabilize the economy, and distribute income. Government spending and tax revenue as the primary fiscal policy tool Fiscal policy aim to allocate resources, stabilize the economy and distribute income - government spending and tax revenue as the primary fiscal policy tool (Tanzi, 2008). Fiscal policy through a budget deficit is aimed at stimulating the economy through the supply and demand side. On the demand side, the increase in income originates from an increase in private consumption, investment, government spending, an increase in exports, and a decrease in imports. Keynes's understanding states that fiscal policy through an increase in government spending is intended to boost demand. Through fiscal policy, aggregate demand increases and occurs when the components of the goods market or real sector increase.

Fiscal policy as a form of government intervention in the economy is intended to maintain economic, political, socio-cultural, and defense stability. Fiscal policy instruments include government spending (G) and taxes (T) together with consumption variables $(\mathrm{C})$, investment $(\mathrm{I})$, and net exports $(\mathrm{XM})$, which are components that affect national output or income $(\mathrm{Y})$. In the macroeconomic balance formulated:

$$
\mathrm{Y}=\mathrm{C}(\mathrm{YT})+\mathrm{I}(\mathrm{r} *)+\mathrm{G}+\mathrm{NX}(\mathrm{e})
$$

Financial market equilibrium, in which real money demand is negatively affected by the interest rate (equal to $\mathrm{r} *$ ), and positively by income. The formula can be written:

$$
\mathrm{M} / \mathrm{P}=\mathrm{L}(\mathrm{r} *, \mathrm{Y})
$$

The balance of the goods market and the money market according to the MundellFleming model, is expressed by two equations:

$$
\begin{aligned}
& \mathrm{Y}=\mathrm{C}(\mathrm{YT})+\mathrm{I}\left(\mathrm{r}^{*}\right)+\mathrm{G}+\mathrm{NX}(\mathrm{e}) \\
& \mathrm{M} / \mathrm{P}=\mathrm{L}\left(\mathrm{r}^{*}, \mathrm{Y}\right)
\end{aligned}
$$

The exogenous variables consist of fiscal policy ( $\mathrm{G}$ and $\mathrm{T})$, monetary policy $(\mathrm{M})$, price level $(\mathrm{P})$, and interest rate $(\mathrm{r} *)$. Endogenous variables consist of income $(\mathrm{Y})$, and exchange rates (e) (Mankiw, 2010).

Expansive fiscal policy has hurt increasing the budget deficit, increasing expenditures exceeding state revenues. Efforts to overcome the deficit can be made through fiscal adjustments (revenue and expenditure) or debit withdrawals. An increase in the deficit can increase fiscal risk. Fiscal risk because of fiscal failure to fulfill obligations. Fiscal adjustment will adversely affect economic growth efforts due to a decrease in output and aggregate demand. This effort is closely related to maintaining the deficit. A budget deficit is needed so that economic growth can occur in the short and long term (Aldama and Creel, 2019). The government debt to GDP ratio becomes 
an essential variable in fiscal sustainability. Increasing debt in the fiscal consolidation process does not always lead to a reduction in the debt-to-GDP ratio. It shows that it balances and adjusts once the debt reaches a specific limit.

\subsection{Budget Deficit}

The budget deficit shows the fiscal conditions that can meet spending (Adam, 2011). The budget deficit indicates that the fiscal condition cannot finance all expenditures for an indefinite period (Langenus, 2006). Consequently, the budget deficit must be able to take into account fiscal vulnerability. Vulnerabilities that arise from direct liabilities can be predicted in advance, and contingent liabilities due to any event beyond its control (Brixi and Schick, 2002). Deficit budget is closely related to fiscal capacity, which is shown from the primary balance. Indonesia's primary balance from 2008 until now shows a negative number. This indicates the fiscal inability to finance all expenses from its income and does not include debt installments and interest payments.

An increase in debt in a budget deficit condition will have the potential to form debt accumulation. The accumulation results from the withdrawal of new debt to meet debt obligations that are past due. This condition will have a terrible influence on increasing the economy and distributing people's income. As a result, part of government spending is allocated to pay the debt and interest installments. In several studies, excessive budget deficits have become the focus of fiscal policy in several countries. Mainly as a result of increased spending. If there is a slight increase in spending in a deficit condition, it will significantly reduce fiscal performance. This is because the government tends to use debt instruments to cover the budget deficit. The increase in debt will reduce fiscal performance; this is because part of the expenditure is allocated to pay debts that are past due. An increase in the budget deficit is closely related to an increase in government spending. The subsidy spending policy, which is intended to increase the people's purchasing power and producers' ability to produce, has affected increasing government spending. Amid the budget deficit and increasing spending, efforts are needed to optimize the deficit. Limiting the deficit is a measure to maximize fiscal performance, which increases the quality of spending.

\subsection{Impact of Government Expenditure Against the Optimal Economy}

When the economy goes into recession, the government intervenes through fiscal policy. Meanwhile, according to Keynes, an increase in government spending in the short term will result in economic growth. Research by Al-Yousif (2000) found a positive relationship between government spending and economic growth; Ramayandi (2003) states that government spending hurts Indonesia's economic growth. Government spending is an essential component in economic growth. An increase in expenditure will directly increase aggregate expenditure. In the first stage of the multiplier process, an increase in spending will raise national income. How big is the impact of increasing government spending will increase national income (Romer, 1996)? The IS curve reflects the equilibrium in the goods market. 


\subsection{Role of Control Optimum in Economy}

Tehranchian and Rad (2007) stated that macroeconomic policies' optimal value has a deviation from that proposed in the third development plan. The deviation in the current expenditure variable, namely, government tax revenue and government oil revenue, is low, and the variables of government capital expenditure and money stocks as financial policies are high. Optimal fiscal and financial policy is determined as a solution to the optimal control problem with the scientific object's function and the macroeconomic model as a constraint. This model analyzes the optimality of macroeconomic policies in Iran during the third five-year development plan (20002004). Correani et al. (2014) examined the fiscal policy's effectiveness on output determined by demand or supply. The method used is to use a mathematical model using the Hamilton Jacobi Bellman equation to minimize the integral operator in which the variables are described in the stochastic differential equation with control. The results show that economic activity is driven by demand (the price level is assumed to be completely rigid), and as a result, active fiscal policy (public spending or taxation) will spread through a multiplier mechanism, giving rise to a rapid expansion of output.

Meanwhile, Abdi Rad and Zadeh (2009) used the Stochastic optimal control algorithm to determine the optimal fiscal policy and monetary policy to solve the optimal control problem with the quadratic objective function, and the constraint function is a macro econometric model. This study uses data from the Iranian Development plan for 2005-2009 using 36 state variables (endogenous), eight exogenous non-control variables, and five exogenous control variables. From the research results, it is found that the optimal value of government spending, government capital expenditures, tax revenues, and oil revenues as a series of fiscal policies is more significant than that proposed in the fourth development plan. Meanwhile, the money stock as a monetary policy is less than proposed. Is more significant than that proposed in the fourth development plan.

Neck and Karbuz (1998) conducted a study on the optimal stabilization policy for the 1995-2000 period in Austria, which was calculated using various assumptions of stochastic parameters in a quantitative economic policy framework. The objective function minimizes the intertemporal subject by constraining a macroeconomic model. This research shows that the optimal value of central government revenue and expenditure is close to the determined target. Research by Blueshke et al. (2016) considers optimal control of two stochastic models in the Slovenian economy by applying the control optimization algorithm (OPTION). OPTION specifies a numerical solution approach for optimal control problems in nonlinear stochastic systems and is particularly applicable to econometric models. Researchers compared applying the OPTCON2 version of the Algorithm for the nonlinear SLOVNL model and the SLOVL linear model. The results for both models are the same. Using the open-loop feedback control gives better results, but there are more outliers than openloop control. 
Research conducted by Manning (1995) applies optimal control to the national economy. Optimal control is applied under the national economic model's ideal conditions to obtain the main output. In the research conducted, closed-loop control shows that relatively small policy instrument settings are needed to compensate for the sizeable differences. The parameters were estimated using data from the Australian Bureau of Statistics, which includes 60 quarterly data. The constructed model consists of 3 inputs, three outputs, 14 states, and 45 parameters set in discrete time.

\section{Methodology}

\subsection{The Keynesian Simultaneous Macroeconomic Model of Equations}

The model built in this study uses a simultaneous Keynesian macroeconomic model. This is because fiscal policy variables through budget deficits and macroeconomic variables have a relationship. Where the independent variable in one equation can appear as the dependent variable in another equation. Simultaneous equation models describe the relationship between related variables, namely between fiscal variables and macroeconomic variables. The relationship between variables can be formulated. The simultaneous equation model formulation, based on economic theory and empirical facts, shows the direct or indirect relationship between fiscal policy through the budget deficit as a control variable on the Indonesian economy's performance. Keynesian Macroeconomic Model. Equation of Behavior:

a. Household Consumption:

$$
\mathrm{CRT}_{\mathrm{t}}=\mathrm{a}_{11}+\mathrm{a}_{12} \mathrm{GDP}_{\mathrm{t}}+\mathrm{a}_{13} \mathrm{CRT}_{\mathrm{t}-1}+\mathrm{u}_{1 \mathrm{t}}
$$

Where:

$\mathrm{CRT}_{\mathrm{t}} \quad=$ Household Consumption, Real (billion Rp)

$\mathrm{GDP}_{\mathrm{t}}=$ Income real (billion $\mathrm{Rp}$ )

$\mathrm{CRT}_{\mathrm{t}-1}=$ Previous Year's Household Consumption (billion Rp)

\section{b. Total Investment}

$$
\mathrm{INV}_{\mathrm{t}}=\mathrm{a}_{21}+\mathrm{a}_{22} \mathrm{GDP}_{\mathrm{t}}+\mathrm{a}_{23} \mathrm{R}_{\mathrm{t}}+\mathrm{a}_{24} \mathrm{INV}_{\mathrm{t}-1}+\mathrm{u}_{2 \mathrm{t}}
$$

Where:

c. Export

$$
\begin{array}{ll}
\mathrm{INV}_{\mathrm{t}} & =\text { Total real investment (billion Rp) } \\
\mathrm{GDP}_{\mathrm{t}} & =\text { Gross Domestic Product (billion Rp) } \\
\mathrm{R}_{\mathrm{t}} & =\text { Domestic Interest Rate (\%) } \\
\mathrm{INV}_{\mathrm{t}-1} & =\text { Previous Year's Investment (billion Rp) }
\end{array}
$$

$$
\mathrm{EX}_{\mathrm{t}}=\mathrm{a}_{31}+\mathrm{a}_{32} \mathrm{XR}_{\mathrm{t}}+\mathrm{a}_{34} \mathrm{INVR}_{\mathrm{t}}+\mathrm{u}_{3 \mathrm{t}}
$$

Where: 
$X R_{t} \quad=$ Exports (billion $\mathrm{Rp}$ )

$X R_{t} \quad=$ Exchange Rate $(\mathrm{Rp} / \mathrm{US} \$)$

$I N V_{t} \quad=$ Investment (billion Rp)

\section{d. Imports}

$$
\mathrm{M}_{\mathrm{t}}=\mathrm{a}_{41}+\mathrm{a}_{42} \mathrm{GDP}_{\mathrm{t}}+\mathrm{a}_{43} \mathrm{XR}_{\mathrm{t}}+\mathrm{a}_{44} \mathrm{MR}_{\mathrm{t}-1}+\mathrm{u}_{4 \mathrm{t}}
$$

Where:

$\mathrm{M}_{\mathrm{t}} \quad=$ Imports (billion Rp)

$\mathrm{GDP}_{\mathrm{t}}=$ Gross Domestic Product (billion Rp)

$\mathrm{XR}_{\mathrm{t}} \quad=$ Exchange Rate ( $\mathrm{Rp} / \mathrm{US}$ \$)

$\mathrm{M}_{\mathrm{t}-1}=$ Previous Year's Imports (billion Rp)

Identity Equation:

e. Gross Domestic Product

$$
\mathrm{GDP}_{\mathrm{t}}=\mathrm{CRT}_{\mathrm{t}}+\mathrm{INV}_{\mathrm{t}}+\mathrm{Def}_{\mathrm{t}}+\mathrm{EX}_{\mathrm{t}}-\mathrm{M}_{\mathrm{t}}
$$

Where:

$$
\begin{array}{ll}
\mathrm{GDP}_{\mathrm{t}} & =\text { Gross Domestic Product (billion Rp) } \\
\mathrm{CRT}_{\mathrm{t}} & =\text { Household Consumption (billion Rp) } \\
\mathrm{INV}_{\mathrm{t}} & =\text { Investment (billion Rp) } \\
\mathrm{Def}_{\mathrm{t}} & =\text { Budget Deficit (billion Rp) } \\
\mathrm{EX}_{\mathrm{t}} & =\text { Exports (billion Rp) } \\
\mathrm{M}_{\mathrm{t}} & =\text { Imports (billion Rp) }
\end{array}
$$

The first stage: Identification of Simultaneous Equations. In the simultaneous equation model, the model's identification is determined based on "order condition" as a requirement and "rank condition" as a requirement of sufficiency. Identify a simultaneous equation model so that it can be estimated through order conditions determined by:

$$
(\mathrm{KM}) \geq(\mathrm{G}-1)
$$

Where:

$\mathrm{K}=$ number of endogenous and predetermined variables in the simultaneous equation model,

$\mathrm{M}=$ number of endogenous and exogenous variables in a given equation in the model,

$\mathrm{G}=$ number of equations in the simultaneous model, namely the number of endogenous variables in the model. 
The identification results for each structural equation must meet the over-identified or precisely identified condition so that the parameters can be guessed. Even though the order condition has been met, it is not sufficient to determine the identifiable equation. One of the necessary conditions that must exist is the rank condition. From the rank condition of an equation in a system of simultaneous equations, which consists of $\mathrm{G}$, it can be identified if it is possible to form at least one non-zero determinant of size (G-1) of the variables removed from absolute equations but entered other equations.

Based on the order conditions and the rank conditions have been met, the Two-Stage Least Square (2SLS) method is used in the simultaneous structural equation. The 2SLS method is to get one estimator for one parameter and produce a standard error for each estimator. Furthermore, to evaluate the model based on statistical criteria, it can be done by looking at the coefficient of determination R2, t statistic, and the Durbin Watson statistical test (Gujarati, 1994).

\subsection{Optimal Control Model}

Determining the optimal control policy on an economic problem is carried out by considering several other factors that change dynamically and can be formulated as an optimal control model. Optimal control is a dynamic mathematical optimization involving differential equations (continuous cases) or difference equations (discrete cases). In this research, discrete dynamic optimal control will be used to obtain an optimal fiscal policy. The optimum control problem is a problem of choosing a control variable among all admissible control variables, namely a control that takes the system from the initial state at the initial time to the final state at the end time, to provide a maximum or minimum value for the objective function (Kendrick, 1981). Control variables and state variables in differential equations or differential equations in optimal control models represent various economic theory parameters. In this study, the problems studied involve control in the economy in fiscal policy, namely the budget deficit, while the dynamic system is the Keynesian macroeconomic model, and the target is a stable economy.

This study's discrete optimal control problem is to minimize the objective function in the form of a quadratic function against deviations in the state variable and the control variable from the target value. The quadratic form of the objective function mathematically guarantees a single solution. This means that the minimalization of the quadratic function has a single extreme point. The state and control variables' target values in the objective function are given so that the optimum state and control variable values approach the expected values for each observed time. Meanwhile, the constraint function is in the form of a macroeconomic model of the economy in Indonesia. The optimal control model used in general can be written as follows:

$$
\text { Min objective function } L=\frac{1}{2} \sum_{t=1}^{\mathrm{T}}\left[\begin{array}{c}
\mathrm{x}_{\mathrm{t}}-\breve{\mathrm{x}}_{\mathrm{t}} \\
\mathrm{u}_{\mathrm{t}}-\breve{\mathrm{u}}_{\mathrm{t}}
\end{array}\right]^{\prime} \mathrm{W}_{\mathrm{t}}\left[\begin{array}{l}
\mathrm{x}_{\mathrm{t}}-\breve{\mathrm{x}}_{\mathrm{t}} \\
\mathrm{u}_{\mathrm{t}}-\breve{\mathrm{u}}_{\mathrm{t}}
\end{array}\right]
$$


Against obstacles, $\mathrm{x}_{\mathrm{t}}=\mathrm{Ax}_{\mathrm{t}-1}+\mathrm{Bu}_{\mathrm{t}}+\mathrm{Cz}_{\mathrm{t}}, \quad \mathrm{t}=1, \ldots, \mathrm{T}$

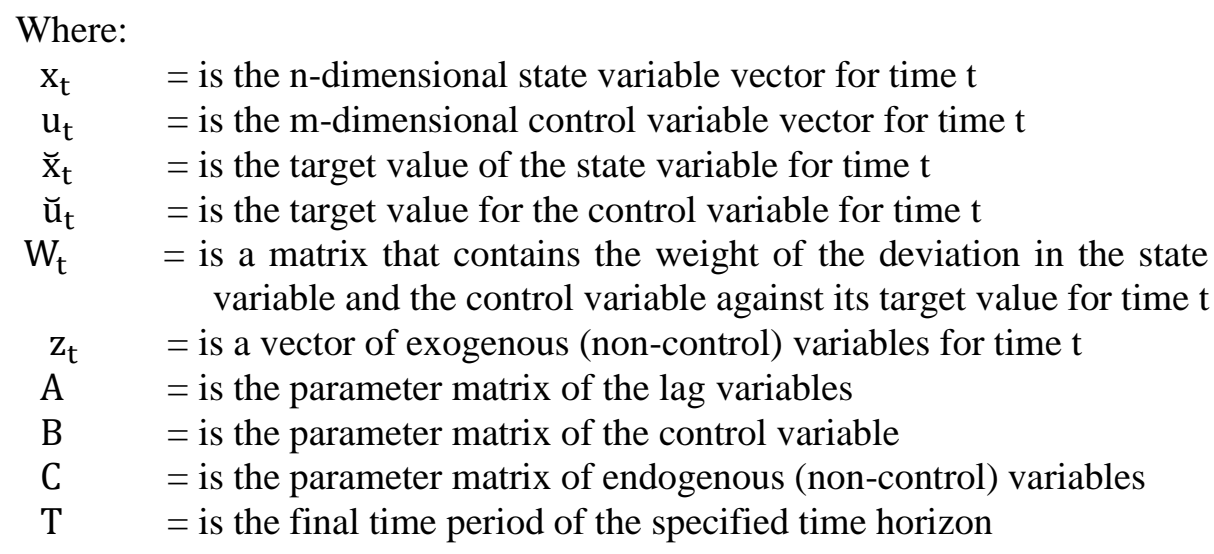

The variables used in Keynes's economic model in this study consisted of 3 types of variables, namely:

Endogenous Variable (State):

$x[1]: C R T \quad=$ Household consumption

$x[2]: I N V \quad=$ Total real investment

$x[3]: E R \quad=$ Export

$x[4]: M \quad=$ Import

$x[5]: G D P \quad=$ Gross Domestic Product

Control Variables:

$u[1]:$ Def $\quad=$ Budget Deficit

Exogenous variables (non-control):
$z[1]: R$
$=$ Domestic Interest Rate
$z[3]: X R$
$=$ Exchange Rate

The model in this study uses an optimum control dynamic model. The initial conditions for the state and control variables are given. The initial value is the final value of the estimated time horizon. The target value of the state variable and the control variable $\left(\breve{x}_{t}\right.$ dan $\left.\breve{u}_{t}\right)$ in the objective function is given based on the growth rate $(\%)$ at the last value on the observation time horizon.

The constant matrix weight $\mathrm{W}$ on the objective function is the determination of the weight of the variable, where each variable is given the same weight, namely 1 (one) describes that each variable is expected to contribute or have the same role to achieve the optimum value, meanwhile, if given a greater weight, this means that it is prioritized to achieve the target. 


\section{Results and Discussion}

\subsection{Estimation Results}

$\mathrm{T} \mathrm{O}$ see the effect of fiscal policy through the budget deficit on the economy, then determining the constraint function of optimal control requires each parameter of the Keynesian macroeconomic model estimate. The estimation of the macroeconomic model in this study uses a two-stage least square (2SLS) because, in the previously described model, an identity equation produces a biased estimator when estimating using OLS (Table 1). The estimation generated by the 2SLS is used for prediction and optimization models. The estimation results can be seen as follows:

Table 1. 2SLS Consumption Regression Results (CRT)

\begin{tabular}{ccccc}
\hline Variable & Efficient & Standard error & T statistic & Prob \\
\hline C & -12994.37 & 27135.06 & -0.478878 & 0.6362 \\
Y & 0.175699 & 0.030037 & 5.849318 & 0.0000 \\
CRT (-1) & 0.723141 & 0.055717 & 12.97889 & 0.0000 \\
\hline R-Squared & 0.995 & & & \\
Adj R-Squared & 0.998 & Instrument Rank & & \\
F-Stat & 8354.87 & & & \\
\hline
\end{tabular}

Source: Own study.

The first estimation result is the household consumption estimate. In theory, consumption in terms of household expenditure is very dependent on the amount of income. If income increases, consumption will also increase. The results show that income has a positive and significant effect. Meanwhile, household consumption is also very dependent on consumption in the past, and the results show a positive and significant effect (Table 2).

Table 2. 2SLS Investment Regression Results (INV)

\begin{tabular}{ccccc}
\hline Variable & Efficient & Standard error & T statistics & Prob \\
\hline C & 382013.8 & 83738.25 & 4.561999 & 0.0001 \\
Y & -0.042516 & 0.043010 & -0.988522 & 0.3328 \\
R & -18579.50 & 2579,094 & -7.203888 & 0.0000 \\
INV (-1) & 1.117192 & 0.122226 & 9.140401 & 0.0000 \\
\hline R-Squared & 0.993 & & & \\
Adj R-Squared & 0.992 & Instrument Rank & 7 & \\
F-Stat & 1213.48 & & & \\
\hline
\end{tabular}

Source: Own study.

The 2SLS results show that the Y value hurts investment, which means that the investment increase is not significant to the decline in economic growth. This condition results from international economic uncertainty, which has impacted global financial market conditions and investment risk in developing countries (investment experiences outflows). Indonesia also experiences this. The investment estimate examined in this study uses income, interest rates, and previous investments. The 
income coefficient has a negative sign, which indicates that the economy is not doing well. Meanwhile, a positive sign means that the economy is improving (Table 3 ).

Table 3. 2SLS Export Regression Results (EX)

\begin{tabular}{ccccc}
\hline \multicolumn{1}{c}{ Variable } & Efficient & Standard error & T statistics & Prob \\
\hline C & 82816.18 & 63139.45 & 1.311639 & 0.2016 \\
XR & 27,26918 & 8.659863 & 3.148916 & 0.0042 \\
INV & 0.570754 & 0.043230 & 13.20278 & 0.0000 \\
\hline R-Squared & 0.948 & & & \\
Adj R- & 0.944 & Instrument Rank & 7 & \\
Squared & 233.40 & & & \\
F-Stat & & & & \\
\hline
\end{tabular}

Source: Own study.

In an open economy, exports are the primary determinant of economic growth. However, the increase in exports depends on the rupiah exchange rate and investment. In theory, the two variables have a positive effect, and the estimation results in Table 3 show conformity to the theory and are significant at 1 percent level.

Table 4. 2SLS Import Regression Results (M)

\begin{tabular}{ccrcc}
\hline Variable & Efficient & Standard error & T statistics & Prob \\
\hline C & 9641,507 & 80650.06 & 0.119547 & 0.9058 \\
Y & 0.038090 & 0.052624 & 0.723816 & 0.4762 \\
XR & -21.29704 & 12,21238 & -1.743889 & 0.0940 \\
M (-1) & 1.003877 & 0.239425 & 4.192868 & 0.0003 \\
\hline R-Squared & 0.922 & & & \\
Adj R-Squared & 0.913 & Instrument Rank & 7 & \\
F-Stat & 100.34 & & & \\
\hline
\end{tabular}

Source: Own study.

Unlike exports, the rupiah exchange rate has a different sign, which is a negative effect. The effect of this variable has a significant effect at the 10 percent level. However, previous income and imports from the results of Table 4 above explain that they have a positive sign and significantly affect imports.

\subsection{Optimal Control Model}

The Keynesian econometric model discussed earlier is a system of equations that must be met in determining the value of the variables (state and control) at the time of prediction to optimize an objective function. Furthermore, L's objective function is defined, which states the closeness of each variable's value to the target to be achieved at each observation time. Since the variable value is expected to be as close as possible to the given target value, the objective function is to minimize the value of L. Thus, the optimal control system with the objective function as described and the constraints of the econometric equation is as follows:

Min objective function $L=\frac{1}{2} \sum_{t=1}^{T}\left[\begin{array}{c}x_{t}-\breve{x}_{t} \\ u_{t}-\breve{u}_{t}\end{array}\right]^{\prime} W_{t}\left[\begin{array}{c}x_{t}-\breve{x}_{t} \\ u_{t}-\breve{u}_{t}\end{array}\right]$ 
Against obstacles, $x_{t}=\Pi y_{t}+\Gamma U_{t}, \quad t=1, \ldots, T$

$$
x_{t 0}=x_{0}
$$

Where:

$$
x_{t}=\left(\begin{array}{c}
C R T_{t} \\
I N V_{t} \\
E x_{t} \\
M_{t} \\
Y_{t}
\end{array}\right), u_{t}=D e f_{t} y_{t}=\left(\begin{array}{c}
I \\
C R T_{t-1} \\
i_{t} \\
I N V_{t-1} \\
X R \\
M_{t-1}
\end{array}\right)
$$

With the initial value taken from the final value of the data before the simulation year.

$$
\begin{aligned}
& x_{t 0}=\left(\begin{array}{c}
C R T_{t 0} \\
I N V_{t 0} \\
E x_{t 0} \\
M_{t 0} \\
Y_{t 0}
\end{array}\right)=\left(\begin{array}{c}
5774124.5 \\
3444118.4 \\
2285871.9 \\
2201127.4 \\
10425316.3
\end{array}\right), u_{t}=D e f_{t}=325937 \\
& \text { Target value: } \breve{x}_{t}=\left(\begin{array}{c}
I \overline{C R T} \\
I \overline{E V} \\
\widetilde{M} \\
\check{Y}
\end{array}\right)
\end{aligned}
$$

The target value of the state variable and the control variable (value. $\breve{x}_{t}$ dan $\breve{u}_{t}$ ) in the Objective function is based on the growth rate $(\%)$ at the last value on the observation time horizon. The constant matrix weight $\mathrm{W}$ on the objective function determines the weight of the variable, where each variable is given the same weight, namely 1 (one), to describe that each variable is expected to contribute or have the same role in achieving the optimum.

\subsection{Optimal Control Simulation Results}

Fiscal policy simulations through the budget deficit as government control are carried out to determine optimal results for public consumption, government investment, exports, imports, and GDP. The state variable and control variable's initial value in the objective function is defined based on the last value in the observation time horizon. Policy simulations were selected in the 2019-2023 period. The constraint function of optimum control is a reduced form of the Keynesian macroeconomic model. From the calculation results using the fmincon function feature in Matlab, optimal results are obtained for the state and control variables' value as in Table 5. 
Intan Syahrini, Yusri Hazmi, Raja Masbar, Aliasuddin, Said Munzir

Table 5. Optimal Value Results and Target Value (Billion Rupiah)

\begin{tabular}{|c|c|c|c|c|c|c|c|}
\hline & & & 2019 & 2020 & 2021 & 2022 & 2023 \\
\hline \multirow{16}{*}{$\begin{array}{l}\text { Variable } \\
\text { State }\end{array}$} & \multirow{4}{*}{ CRT } & Target & $6,062,830.73$ & $6,365,972.26$ & $6,684,270.87$ & $6,684,270.87$ & $7,018,484.42$ \\
\hline & & & & & & & \\
\hline & & Optimal & $6,068,292.99$ & $6,000,000.00$ & $6,067,245.74$ & $6,062,234,31$ & $6,066,269.98$ \\
\hline & & Deviation & $5,462.27$ & $365,972.26$ & $617,025.00$ & $622,036.56$ & $952,214.44$ \\
\hline & \multirow{3}{*}{ INV } & Target & $3,650,765,504$ & $3,869,811,434$ & $4,102,000.12$ & $4,348,120,128$ & $4,609,007.34$ \\
\hline & & Optimal & $3,648,679.75$ & $3,609,776.16$ & $3,648,311.43$ & $3,650,297.77$ & $3,647,952.50$ \\
\hline & & Deviation & $2,085.75$ & $260,035.27$ & $453,688.69$ & $697,822,358$ & $961,054.84$ \\
\hline & \multirow{3}{*}{ EX } & Target & $2,429,881.83$ & $2,582,964,385$ & $2,745,691,141$ & $2,918,669,683$ & $3,102,545,873$ \\
\hline & & Optimal & $2,428,413.16$ & $2,429,385.03$ & $2,428,307.32$ & $2,429,441.12$ & $2,428,206.84$ \\
\hline & & Deviation & $1,468.67$ & $153,579.36$ & $317,383.82$ & $489,228.56$ & $674,339.03$ \\
\hline & \multirow{3}{*}{ M } & Target & $2,062,456,374$ & $1,932,521,622$ & $1,810,772.76$ & $1,696,694,076$ & $1,589,802,349$ \\
\hline & & Optimal & $2,063,265,020$ & $2,061,744.92$ & $2,063,467.96$ & $2,061,594.77$ & $2,063,483.05$ \\
\hline & & Deviation & 808,650 & $129,223.29$ & $252,695.20$ & $364,900.69$ & $473,680.70$ \\
\hline & \multirow{3}{*}{ GDP } & Target & $10,977,858.06$ & $11,592,618.12$ & $12,288,175,2$ & $13,086,906.59$ & 14.002 .99005 \\
\hline & & Optimal & $11,021,452.78$ & $11,004,047.09$ & $11,009,218.03$ & $11,005,453.56$ & $11,007,797.96$ \\
\hline & & Deviation & $43,594.72$ & $588,571.03$ & $1,278,957.17$ & $2,081,453.03$ & $2,995,192.09$ \\
\hline \multirow{3}{*}{$\begin{array}{l}\text { Control } \\
\text { Variable }\end{array}$} & \multirow{3}{*}{ Def } & Target & $329,196,370$ & $332,488,3337$ & $335,813,217$ & $339,171,3492$ & $342,563,0627$ \\
\hline & & Optimal & $329,110,230$ & $300,000,000$ & $300,000,000$ & $300,000,000$ & $300,000,000$ \\
\hline & & Deviation & 86.14 & $32,488,330$ & $35,813,220$ & $39,171,350$ & $42,563,060$ \\
\hline
\end{tabular}

Source: Own study.

Based on Table 5, the estimated initial year (2019) shows that the optimal value of consumption (CRT) in the initial year of the estimate is greater than the consumption target value determined by the government. Whereas for the estimation of the following year (2020-2023), the optimal value of consumption (CRT) is smaller than the government's target value. The average deviation value of consumption in the simulation period is Rp510,357.23 billion. The optimal investment value (INV) during the simulation period (2019-2023) is less than the government's target value.

The average deviation value of an investment in the simulation period amounted to Rp 961,054.84 billion. The optimal export value (EX) during the estimation period is less than the government's export target value. The average export deviation value in the simulation period was IDR 327,199.89 billion. The optimal import value (M) at the beginning of the estimated period (2019) is greater than the government's import target value. The average import deviation value in the simulation period was IDR $244,261.71$ billion. The optimal value of GDP during the initial estimate (2019) is greater than the government's GDP target value, while for the next estimate (20202023), the optimization value is below the target value. The average deviation value of GDP in the simulation period amounted to IDR 1,380,115.72 billion. The optimal value of the budget deficit (Def) during the estimation period (2019-2023) is less than the government's budget deficit target value. The average budget value in the simulation period is IDR $300,244,205$ billion. 
In this case, the government's target is based on the movement of the annual average growth of each variable. To achieve the optimal value is done through controlling the deficit (optimal deficit). By controlling the optimal budget deficit, it will produce optimal values for each variable. For the deviation value, the smaller the deviation value, the closer the optimal value to the target value, the better, meaning that because the objective function of the optimal control model is to minimize the deviation between the target value and the optimal value.

Table 6. Optimal Contribution and Target of Macroeconomic Variables to GDP (percent)

\begin{tabular}{|c|c|c|c|c|c|c|c|c|}
\hline & & & 2019 & 2020 & 2021 & 2022 & 2023 & Average \\
\hline \multirow{8}{*}{$\begin{array}{l}\text { State } \\
\text { Variable }\end{array}$} & \multirow[b]{2}{*}{ CRT } & Target & 55.23 & 55.91 & 54.40 & 51.08 & 50.12 & 53.15 \\
\hline & & & 5505 & 5453 & 5511 & 5508 & 5512 & 5498 \\
\hline & \multirow{2}{*}{ INV } & Target & 33.26 & 33.38 & 33.38 & 33.22 & 32.91 & 33.23 \\
\hline & & Optimal & 33.11 & 32.80 & 33.14 & 33.17 & 33.14 & 33.07 \\
\hline & \multirow{2}{*}{ EX } & Target & 22.13 & 22.28 & 22.34 & 22.30 & 22.15 & 22.24 \\
\hline & & Optimal & 22.03 & 22.08 & 22.06 & 22.07 & 22.06 & 22.06 \\
\hline & \multirow[b]{2}{*}{ M } & Target & 18.79 & 16.67 & 14.74 & 12.96 & 11.35 & 14.90 \\
\hline & & Optimal & 18.72 & 18.74 & 18.74 & 18.73 & 18.75 & 18.74 \\
\hline \multirow{2}{*}{$\begin{array}{l}\text { Control } \\
\text { Variable }\end{array}$} & \multirow[b]{2}{*}{ Def } & Target & 2.99 & 2.87 & 2.73 & 2.59 & 2.45 & 2.73 \\
\hline & & Optimal & 2.99 & 2.73 & 2.72 & 2.73 & 2.73 & 2.77 \\
\hline
\end{tabular}

Source: Own study.

Table 6 shows the contribution of consumption (CRT) to GDP in the simulation period (2019-2020), which shows that the contribution value of consumption to the optimal value is smaller than the target growth. Meanwhile, for the next period (202123 ), consumption to the optimal value is greater than the target contribution. For the simulation period (2019-2023), the contribution of optimal consumption on average shows a value of 54.98 percent to GDP and is greater than the average contribution of target consumption which is 53.15 percent. The investment contribution (INV) to GDP in the simulation period (2019-2023) shows that the optimal value investment contribution is smaller than the target contribution.

For the simulation period (2019-2023), the optimal investment contribution on average shows a value of 33.07 percent and is smaller than the average contribution target. The contribution of export value (EX) to GDP in the simulation period (20192023) shows that the optimal export contribution is smaller than the target contribution, where the optimal contribution value of the average export shows a value of 22.06 percent. The contribution of import value (M) to GDP in the initial simulation period (2019) shows that imports' optimal contribution value is smaller than the target value. For the next simulation period (2020-2023), the average import contribution's optimal value is greater than the target value. For the simulation period (2019-2023), the average imports to GDP's optimal value show a value of 18.74 and are more significant than the average import target value. 
The contribution value of the budget deficit (Def) to GDP in the initial simulation period (2019) shows that the budget deficit's optimal contribution value to GDP is the same as the target value. For the next simulation period (2020-2021), the optimal value of the average contribution to the budget deficit is smaller than the target value. On the other hand, for the simulation period (2022-2023), the budget deficit contribution's optimal value is greater than the target value. For the simulation period (2019-2023), the optimal value of the average budget deficit contribution to GDP shows a value of 2.77 and is greater than the average deficit target value.

On the other hand, for the simulation period (2022-2023), the budget deficit contribution's optimal value is greater than the target value. For the simulation period (2019-2023), the optimal value of the average budget deficit contribution to GDP shows a value of 2.77 and is greater than the average deficit target value. On the other hand, for the simulation period (2022-2023), the budget deficit contribution's optimal value is greater than the target value. For the simulation period (2019-2023), the optimal value of the average budget deficit contribution to GDP shows a value of 2.77 and is greater than the average deficit target value.

Thus, to encourage optimal contribution and target variables to macroeconomics, efforts to control the deficit (optimal deficit) are needed. So far, the government has not controlled the deficit (floating deficit). Of course, this is less meaningful for improving macroeconomic quality (performance), such as household consumption, investment, exports, and imports.

\section{Conclusions and Recommendations}

Simulation of the impact of optimal control on fiscal policy on the Indonesian economy 2019-2023. To obtain economic growth, including consumption, investment, export, import, and GDP, the government needs to control the budget deficit. The optimal contribution of consumption to GDP for the simulation is not too different from the real value, which is an average of 0.2 percent. Meanwhile, the investment growth towards GDP for simulations is different from the real one, namely 2.67 percent on average; the difference between the simulation value and real exports is an average of 0.44 percent. The simulated and real value for imports to GDP an average of 2.86 percent. In the control variable budget deficit on GDP, the difference between the simulated and real values is an average of 1.07 percent.

Regarding the control variable, namely the budget deficit, it is recommended to study the limit of the fiscal deficit ratio of 3 percent to GDP. This is because the government can only control the budget deficit through the difference between income and expenditure. This optimal policy can be applied to assume that there will be no recession, inflation, natural disasters, and other factors.

The budget deficit policy and the model used are the Keynesian macroeconomic model. For further research, it is necessary to develop a Keynesian macroeconomic model and add a monetary policy to provide complete analysis results. 


\section{References:}

Abdi Rad, M., Zadeh, A. 2009. Quantitative determination of optimal fiscal and monetary policies: A stochastic optimal control analysis for Iran. Iranian Economic Review, 14(24).

Abimayu, A. 2003. Fiscal Policy in Pro-People Development. Ministry of Finance, Jakrta. Abimayu, A. 2005. Fiscal Policy and the Effectiveness of Fiscal Stimulus in Indonesia: Application of Macro-MODFI and CGE-INDORANI Models. Journal of Indonesian Economics.

Adam, K. 2011. Government debt and optimal monetary and fiscal policy. European Economic Review, 55(1), 57-74. https://doi.org/10.1016/j.euroecorev.2010.11.003.

Aldama, P., Creel, J. 2019. Fiscal policy in the US: Sustainable after all? Economic Modeling, 81, 471-479. https://doi.org/10.1016/j.econmod.2018.03.017.

Algifari. 2005. The Effect of the Government Budget Deficit on the optimal economy in Indonesia.

Al-Yousif, Y. 2000. Do Government Expenditure Inhibit or Promote Economic Growth: Some Empirical Evidence from Saudi Arabia. The Indian Economic Juornal, 48.

Blueschke, D., Nikolaeva, V.B., Neck, R. 2016. Stochastic Control of Econometric Model for Slovenia. HAL ID: p-01286449.

Bose, N., Haque, M.E, Osborn, D.R. 2007. Public Expenditure and Economic Growth: Aggregated Analysis for Developing Countries. The Manchester School.

Brixi, H.P, Schick, A. 2002. Government at Risk: Contingent Liabilities and Fiscal Risk. World Bank.

Bunea-Bontas, C.A., Petre, M.C. 2008. Fiscal Policy During the Current Crisis. JLE Classification: E62, E63, E65.

Correani, L., Di Dio, F., Patri, S. 2014. Optimal choice of fiscal policy instruments in a stochastic IS - LM model. Mathematical Social Sciences, 71, 30-42.

Ezeabasili, V.N.T, Ioraver, N. 2012. Economic Growth and Fiscal Deficits: Empirical Evidence from Nigeria. Economics and Finance Review, 2(6), 85-96.

Gujarati, D.N. 1996. Basic Econometrics (Third Edition ed.). New York: Mc. Graw-Hill International Edition.

Gupta, S., Clemennts, B., Baldacci, E., Mulas-Granados, C. 2005. Fiscal policy, expenditure composition, and growth in low-income countries. Journal of International Money and Finance, 24(3), 441-463.

Kendrick, D.A. 1981. Stochastic Control For Economic Model (Second Edition ed.). Austin, Texas, USA: McGraw-Hill. Inc.

Langenus, G. 2006. Fiscal Sustainability Indicators and Policy Design in the Face of Aging. SSRN Electronic Journal. https://doi.org/10.2139/ssrn.1687700.

Manning, R. 1995. Applying Optimal Control to a Real National Economiy. IFAC Modeling and Control of National and Regional Economies.

Neck, R., Karbuz, S. 1998. Optimal Control of Fiscal Policies fpr Austria: Applications of A Stochastic Control Algorithm. Nonlinear Analysis Theory, Methods \& Applications, 30(2), 1051-1061.

Ramayandi, A. 2003. Economic Growth and Government Size in Indonesia: Some Lesson for Local Authorities. Working Paper in Economics and Development Studies, No 200302. Retrieved from: http://www.equitablepolicy.org/wpaper/200302.pdf

Romer, D. 1996. Advanced Macroeconomics. Singapore: The McGraw-Hill Companies, Inc. 
Saleh, A.S. 2004. Public Sector Deficits and Macroeconomics Performance in Lebanon.

Ph.D. Dissertation, University of Wollongong Australia.

Sukirno, S. 2016. Modern Macroeconomics: The Development of Thought From Classical

To New Keynesian. Raja Grafindo Persada, Jakarta.

Tanzi, V. 2008. The Role of the State and Public Finance in the Next Generation. OECD Journal on Budgeting, 8(2), 7-27.

Tehranchian, A., Rad, M. 2007. Optimality of Monetary and Fiskal Policies in Iran: An Application of the Stochastic Optimal Control Theory. Iranian Economic Review, 13(20), 1-11. 